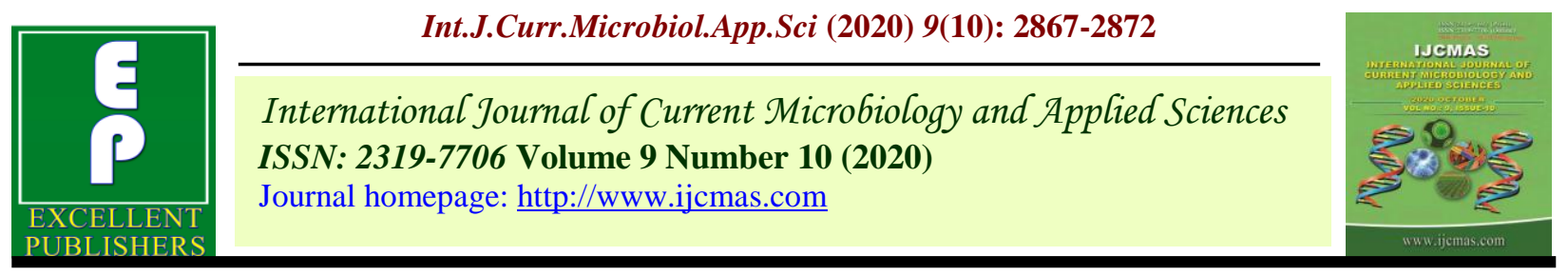

Original Research Article

https://doi.org/10.20546/ijcmas.2020.910.345

\title{
Irrigation Scheduling and Intercropping on Growth and Yield of Aerobic Rice
}

\author{
M. Mahalakshmi ${ }^{*}$, E. Subramanian ${ }^{1}$, A. Gurusamy ${ }^{1}$ and K. Senthil ${ }^{2}$ \\ ${ }^{1}$ Department of Agronomy, ${ }^{2}$ Department of Soils and Environment, Agricultural College and \\ Research Institute, Madurai, India \\ *Corresponding author
}

\section{A B S T R A C T}

\section{Keywords}

Aerobic rice,

Irrigation

scheduling,

Intercropping,

Growth, Yield, LER

Article Info

Accepted:

20 September 2020

Available Online:

10 October 2020

\begin{abstract}
A field experiment was conducted in Central farm of Agricultural College and Research Institute, Madurai during 'Kharif' 2019 to study the irrigation scheduling and intercropping on growth and yield of aerobic rice. The experiment was laid out in strip plot design with twelve treatment combination and replicated thrice. The results found that among the irrigation scheduling, plant height, Leaf area index, Crop growth rate, Dry matter production and also grain and straw yield were recorded higher in irrigation scheduling of Irrigation water / Cumulative pan evaporation ratio 0.8 upto PI thereafter IW/CPE ratio 1.2 and lower in scheduling irrigation at IW/CPE ratio 0.8 upto PI thereafter IW/CPE ratio1. Whereas, intercrop practices rice alone recorded a higher crop growth parameters like, plant height, LAI, CGR, DMP and yield of aerobic rice. Whereas, rice + green gram intercropping system noted in lower growth parameters and yield of aerobic rice. However, LER was higher in rice + black gram intercropping system.
\end{abstract}

\section{Introduction}

Rice is the predominant cereal that is cultivated in area of 43.1 million ha with a total production of 112.9 million tons and its average productivity is 2.6 tons ha ${ }^{-1}$. In Tamil Nadu, rice is cultivated in the area of 1.82 million ha with the production of 8.0 million tons and productivity of 3.5 tons ha ${ }^{-1}$ (India stat, 2017 - 2018).Rice cultivated in the irrigated low land consuming a more amount of water for raising nursery, puddling, transplanting and irrigation. Additional water losses occur mainly through seepage, percolation and evaporation. It's predicted that, it requires $4500-5000$ liters of water to produce one $\mathrm{kg}$ of rice with different system of rice establishment. (Subramanian et al., 2008). Shifting gradually from lowland rice cultivation to aerobic rice system can mitigate the water related problems. Aerobic rice can save as more than $50 \%$ of irrigation water along with labor, nutrients, and other inputs compared with irrigated lowland rice. (Mohana Keerthi et al., 2018). In aerobic rice, to follow an appropriate irrigation scheduling can reduce the water usage for rice production, without affecting the grain yield, increase the water productivity and effective 
utilization of nutrients. In addition to aerobic rice offers the new scope to introduce intercrops on par with other arable crops. Growing of short duration pulses in-between the aerobic rice is the recent advancement to fulfil the requirement of pulses as well as food grains without any reduction of the agricultural area (Subramanian et al., 2020). Keeping this in view, the present study was carried out to study on irrigation scheduling and intercropping on growth and yield of aerobic rice.

\section{Materials and Methods}

A field experiment was conducted at Central farm of the Agricultural College and Research Institute, Madurai during kharif' 2019. The experiment was carried out in a strip plot design with three replications. Main plot treatments are, $\mathrm{M}_{1-}$ IW/CPE ratio 1 upto maturity, $\mathrm{M}_{2}$ - IW/CPE ratio 0.8 upto PI thereafter IW/CPE ratio 1.0 and $\mathrm{M}_{3}-\mathrm{IW} / \mathrm{CPE}$ ratio 0.8 upto $\mathrm{PI}$ thereafter IW/CPE ratio 1.20 and also the subplots had four treatments $S_{1}$ Rice alone, $S_{2}-$ Rice + Green gram (2:1 ratio), $S_{3}-$ Rice + Black gram (2:1 ratio), $S_{4}-$ Rice + Coriander (2:1 ratio). As the main crop were rice (TKM 13) and the intercrops were Green gram (Co 8), Black gram (VBN 6), Coriander (Co (CR) 4). The treated and sprouted paddy seeds used for sowing at the seed rate of $40 \mathrm{~kg} \mathrm{ha}^{-1}$. The spacing of main crop as well as intercrop was $20 \times 10 \mathrm{~cm}$. The soil of experimental site was sandy clay loam. The entire quantity of $\mathrm{P}$ fertilizer applied in basal as a single dose, whereas $\mathrm{N}$ and $\mathrm{K}$ fertilizers were applied in four equal splits at 15 days after sowing (DAS), active tillering (AT), Panicle initiation (PI) and flowering as per the CPG, TNAU (2020). Irrigation water was measured through a parshall flume in open irrigation channel. The observations on growth parameters, grain yield and straw yield were noted and LER were worked out and expressed in $\mathrm{kg} \mathrm{ha}^{-1}$. Gomez and Gomez,
1984, statistically analyzed the collected data. When the treatment differences were found significant ( $\mathrm{F}$ test), critical differences were worked out at five percent probability level to check the significance of treatment's mean. If the treatment differences were non-significant denoted as NS.

\section{Results and Discussion}

\section{Plant height}

The data on plant height at various growth stages were shown in Table 1. Among the irrigation scheduling, irrigation at IW/CPE ratio 0.8 upto $\mathrm{PI}$ thereafter IW/CPE ratio 1.2 $\left(\mathrm{M}_{3}\right)$ noted a taller plants of 104.2 and 105.7 $\mathrm{cm}$ at flowering and harvest stages respectively. The shorter plants of 91.4 and $93.2 \mathrm{~cm}$ were found in irrigation at IW/CPE ratio 0.8 upto $\mathrm{PI}$ thereafter IW/CPE ratio 1.0 $\left(\mathrm{M}_{2}\right)$ during flowering and harvest stages. This might be due to availability of soil moisture which led to uptake of more water and dissolved nutrients which promote a better plant height. Similar results have also been reported by Shekara et al., (2010).

With regards to intercrop practices, taller plants of 104.7 and $106.3 \mathrm{~cm}$ during flowering and harvest stage were registered in rice alone $\left(\mathrm{S}_{1}\right)$. Comparatively, shorter plant height of 92.4 and $93.5 \mathrm{~cm}$ were noticed in rice + green gram $\left(\mathrm{S}_{2}\right)$ intercropping system was due to the luxuriant growth of legumes which over shaded the rice crop and thereby retarding its growth. This is in accordance with the findings of Ahmad et al., (2007).

\section{Leaf area index (LAI)}

The data on Leaf area index at flowering stages which were presented in Table 1. The leaf area index (LAI) determines the total leaf area of rice plant is a feature that is closely associated to grain production because the 
total leaf area at flowering greatly influence on the amounts of photosynthates partitioned to grains. Among the irrigation scheduling, higher LAI of 5.90 during flowering stage were recorded in irrigation scheduling of IW/CPE ratio 0.8 upto PI thereafter IW/CPE ratio 1.2, however, lower LAI were found in irrigation at IW/CPE ratio 0.8 upto PI thereafter IW/CPE ratio 1.0 during the flowering stages under the aerobic rice. This might be attributed to low soil moisture caused the chloroplast damage and oxidation of thylakoid membrane, which led to reduce the photosynthesis due to inhibition of leaf production and decline in leaf area of crop plants under severe water stress condition. (Maheswari et al., 2008).

Regarding intercrop practices, rice alone observed a higher LAI in 5.89 during flowering stage. However, the lower LAI of 4.99 was noted in rice + green gram intercropping system during flowering stages. These results are in akin with earlier reports of Ajayi et al., (2009).

\section{Crop growth rate (CGR)}

The data on CGR at flowering to harvest stage were shown in Table 1. Among the irrigation scheduling, higher CGR $\left(11.2 \mathrm{~g} \mathrm{~m}^{-2}\right.$ day $^{-1}$ ) in the IW/CPE ratio 0.8 upto PI thereafter IW/CPE 1.2 and also irrigation scheduling of IW/CPE ratio 0.8 upto PI thereafter IW/CPE ratio 1.0 recorded lesser CGR (7.59 $\mathrm{g} \mathrm{m}^{-2}$ day $^{-1}$ )during floweringharvest stages. Sandhu et al., (2012) reported that beneficial effect of water in maintaining normal cell integrity, cell elongation and functioning of biopolymers apart from enhancing nutrient uptake which promote a higher crop growth. Regards to intercropping practices, rice alone registered higher CGR $\left(11.6 \mathrm{~g} \mathrm{~m}^{-2}\right.$ day $\left.^{-1}\right)$ and also Rice + green gram showed lesser CGR (6.97 $\mathrm{g} \mathrm{m}^{-2}$ day $^{-1}$ ) during flowering - harvest stage. The similar results were reported by Roy et al., (2015).

Table.1 Irrigation scheduling and intercropping on growth parameters of aerobic rice

\begin{tabular}{|c|c|c|c|c|c|c|}
\hline \multirow[t]{2}{*}{ Treatments } & \multicolumn{2}{|c|}{ Plant height (cm) } & \multirow{2}{*}{$\begin{array}{c}\text { LAI } \\
\text { Flowering }\end{array}$} & \multirow{2}{*}{$\begin{array}{c}\text { CGR } \\
\left(\mathrm{g} \mathrm{m}^{-2} \text { day }^{-1}\right) \\
\text { Flowering } \\
\text { - harvest }\end{array}$} & \multicolumn{2}{|c|}{$\begin{array}{c}\text { DMP } \\
\left(\mathrm{kg} \mathrm{ha}^{-1}\right)\end{array}$} \\
\hline & Flowering & Harvest & & & Flowering & Harvest \\
\hline \multicolumn{7}{|c|}{ Main plot : Irrigation schedule } \\
\hline $\mathbf{M}_{1}$ & 98.2 & 99.6 & 5.49 & 8.82 & 8091 & 12055 \\
\hline $\mathbf{M}_{2}$ & 91.4 & 93.2 & 4.84 & 7.59 & 7275 & 11054 \\
\hline $\mathbf{M}_{3}$ & 104.2 & 105.7 & 5.90 & 11.2 & 8587 & 13306 \\
\hline SEd & 2.14 & 2.11 & 0.15 & 0.36 & 164.5 & 290.5 \\
\hline $\operatorname{CD}(p=0.05)$ & 5.93 & 5.85 & 0.40 & 1.01 & 456.6 & 806.4 \\
\hline \multicolumn{7}{|c|}{ Sub plot : Intercropping } \\
\hline $\mathbf{S}_{1}$ & 104.7 & 106.3 & 5.89 & 11.6 & 8580 & 13474 \\
\hline $\mathbf{S}_{2}$ & 92.4 & 93.5 & 4.99 & 6.97 & 7448 & 11201 \\
\hline $\mathbf{S}_{\mathbf{3}}$ & 96.1 & 97.7 & 5.28 & 8.49 & 7800 & 11684 \\
\hline $\mathbf{S}_{\mathbf{4}}$ & 98.5 & 100.4 & 5.50 & 9.73 & 8110 & 12194 \\
\hline SEd & 2.44 & 2.39 & 0.14 & 0.40 & 191.9 & 322.6 \\
\hline$C D(p=0.05)$ & 5.98 & 5.84 & 0.34 & 0.98 & 469.6 & 789.3 \\
\hline
\end{tabular}


Fig.1 Irrigation scheduling and intercropping on LER



Fig.2 Grain and straw yield of aerobic rice under irrigation Scheduling and intercropping

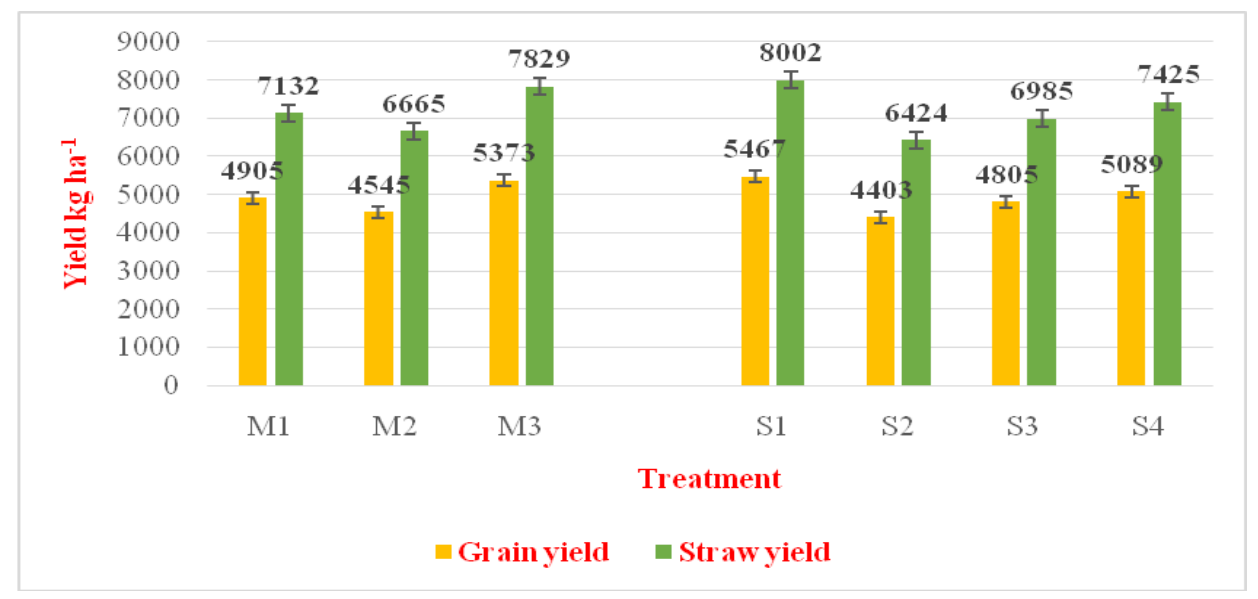

\section{Dry Matter Production (DMP)}

The data on Dry matter production at various growth stages were shown in Table 1. Higher DMP (8587 and $\left.13306 \mathrm{~kg} \mathrm{ha}^{-1}\right)$ were recorded in the irrigation scheduling at IW/CPE ratio 0.8 upto PI thereafter IW/CPE ratio 1.2 and also the lower DMP (7275 and $\left.11054 \mathrm{~kg} \mathrm{ha}^{-1}\right)$ was recorded in irrigating the rice crop at IW/CPE ratio 0.8 upto PI thereafter IW/CPE 1.0 during flowering and harvest stages respectively. Higher DMP might be due to frequent irrigation which leads to higher nutrient and water uptake, lower transpiration rate and also normal gas exchange resulted in higher photosynthates and their translocation to sink (Dari et al., 2017).With respect to intercrop practices, rice alone observed the higher DMP (8580 and $13474 \mathrm{~kg} \mathrm{ha}^{-1}$ ) and the lower DMP (7448 and $11201 \mathrm{~kg} \mathrm{ha}^{-1}$ ) recorded in rice + green gram during flowering and harvest stage respectively. Higher DMP due to increased number of tillers and leaf area index. Similar findings reported by Chu et al., (2004).

\section{Land Equivalent Ratio (LER)}

LER is the most appropriate measure for getting the total productivity on per unit area based on the yield of intercropping over a sole crop. The maximum LER were found in Rice 
+ black gram intercropping system. This might be due to intercropping system obtained a higher yield and its market price coupled with better utilization the agronomic resources more effectively and efficiently towards increased production. These results corroborate the findings of Jabbar et al., (2005) (Fig. 1).

Irrigation scheduling and intercrop practices on grain yield and straw yield of aerobic rice

Higher grain yield of $5373 \mathrm{~kg} \mathrm{ha}^{-1}$ and straw yield of $7829 \mathrm{~kg} \mathrm{ha}^{-1}$ recorded in scheduling irrigation at IW/CPE ratio 0.8 upto PI thereafter IW/CPE ratio 1.2. High level of dry matter production and efficient translocation of photosynthates from source to sink might be responsible for the production of increased level of yield. Whereas scheduling irrigation at IW/CPE ratio 0.8 upto PI thereafter IW/CPE ratio 1.0 noted a lesser grain yield of $4545 \mathrm{~kg} \mathrm{ha}^{-1}$ and straw yield $6665 \mathrm{~kg} \mathrm{ha}^{-1}$. It may be due to lower irrigation frequency which leads to reduce growth and also plant suffered stress during reproductive stage that hampered the supply of photosynthates ensuing poor yield attributes. This was in harmony with findings of Nayak et al., (2015) (Fig. 2).

Among the intercrop practices, rice alone registered a higher grain yield of $5467 \mathrm{~kg} \mathrm{ha}^{-1}$ and straw yield of $8002 \mathrm{~kg} \mathrm{ha}^{-1}$. Noticeably rice + green gram intercropping system noticed lesser grain yield of $4403 \mathrm{~kg} \mathrm{ha}^{-1}$ and straw yield of $6424 \mathrm{kgha}^{-1}$. It may be due to higher yield attributing parameters like number of productive tillers hill ${ }^{-1}$, number of grains panicle ${ }^{-1}$, number of filled grains panicle $^{-1}$ and less number of chaffy grains panicle $^{-1}$ were responsible to give significantly higher grain yield of rice. Similar findings recorded in Venkatesha et al., (2015).
From the above results, it can be concluded that irrigation scheduling of IW/CPE ratio of 0.8 upto PI thereafter IW/CPE ratio of 1.2 noted higher growth attributes and yield. Rice alone recorded higher growth attributes and yield of aerobic rice. Therefore, aerobic rice is highly suitable for low water scarcity area. However, all the intercrops obtained the LER more than one. Hence, intercropping may be tried with short duration pulses in aerobic rice for sustaining the yield.

\section{References}

Ahmad, R., Jabbar, A., Ahmad, A. H., Ullah, E., and Bhatti, I. H. (2007). Evaluation of direct seeded upland rice-based intercropping systems under strip planting geometry. Pakistan J. Agric. Sci, 44(2), 189-193.

Ajayi, E. O., Okeleye, K. A., Olowe, V. I. O., and Okonji, C. J. (2009). Effect of time of intercropping melon with rice on growth and yield of component crops. In Proceedings of the 27th Annual Conference of the Horticultural Society of Nigeria; held in (pp. 371-378).

Chu, G. X., Shen, Q. R., and Cao, J. L. (2004). Nitrogen fixation and $\mathrm{N}$ transfer from peanut to rice cultivated in aerobic soil in an intercropping system and its effect on soil N fertility. Plant and Soil, 263(1), 17-27.

Dari, B., Sihi, D., Bal, S. K., and Kunwar, S. (2017). Performance of direct-seeded rice under various dates of sowing and irrigation regimes in semi-arid region of India. Paddy and water environment, 15(2), 395-401.

Gomez, K., and Gomez, A. (1984). Statistical Procedures for Agriculture Research. A Wiley-Inter Science Publication: John Wiley and Sons, Inc., New York, USA.

Indiastat, (2017-2018). Socio economic statistical information about India. http://www.indiastst.com/default.aspx 
Jabbar, A., Amad, R., Ulla, E., \&Nazir, S. (2005). Agronomic approaches for productivity enhancement of upland rice-based intercropping systems under strip plantation. Pak. J. Agri. Sci, 42(12), 14-17.

Maheswari, J., Bose, J., Sangeetha, S. P., Sanjutha, S., and Priya, R. S. (2008). Irrigation regimes and $\mathrm{N}$ levels influence chlorophyll, leaf area index, proline and soluble protein content of aerobic rice (Oryza sativa L.). International Journal of Agricultural Research, 3(4), 307-316.

Mohana Keerthi, M., Babu, R., Venkataraman, N.S., Subramanian, E. and KarunanandhamKumutha.2018. Effect of Varied Irrigation Scheduling with Levels and Times of Nitrogen Application on Yield and Water Use Efficiency of Aerobic Rice. American Journal of Plant Sciences 9: 2,287-2,296

Nayak, B. R., Pramanik, K., Panigrahy, N., Dash, A. K., and Swain, S. K. (2015). Yield, nitrogen uptake and nitrogen use efficiency indices of aerobic rice (Oryza sativa L.) under various irrigation regimes and nitrogen levels. Int. J. BioResour. Env. Agril. Sci, 1, 8-13.

Roy, S., Barman, M., Puste, A. M., Gunri, S. K., and Jana, K. (2015). Growth, yield, water use efficiency and competitive functions of intercropping system of maize (Zea mays L.) and mungbean (Vigna radiata L.) as influenced by irrigation. SAARC Journal of Agriculture, 13(2), 94-107.

Sandhu, S. S., Mahal, S. S., Vashist, K. K., Buttar, G. S., Brar, A. S., and Singh, M. (2012). Crop and water productivity of bed transplanted rice as influenced by various levels of nitrogen and irrigation in northwest India. Agricultural Water Management, 104, 32-39.

Shekara, B. G., and Krishnamurthy, N. (2010). Effect of irrigation schedules on growth and yield of aerobic rice (Oryza sativa) under varied levels of farmyard manure in Cauvery command area. Indian Journal of Agronomy, 55(1), 3539.

Subramanian, E., James Martin, G., Suburayalu, E. and Mohan, R. 2008. Aerobic rice: water saving rice production technology. In. Proceedings International Water Management Institute - TATA water policy meet, Hyderabad, April, 2-4, 2008, pp. 79-86.

Subramanian E, Sathishkumar $\mathrm{A}$ and $\mathrm{P}$ Rajesh, 2020. Land use efficiency and productivity of rice (Oryza sativa) under various irrigation regimes and intercropping system. Oryza, 57 (2), 146-151.

Venkatesha, M. M., Krishnamurthy, N., Tuppad, G. B. and Venkatesh, K. T. (2015). Effect of intercropping system on yield, yield parameters, nutrient uptake and economics of aerobic rice.

\section{How to cite this article:}

Mahalakshmi, M., E. Subramanian, A. Gurusamy and Senthil, K. 2020. Irrigation Scheduling and Intercropping on Growth and Yield of Aerobic Rice. Int.J.Curr.Microbiol.App.Sci. 9(10): 2867-2872. doi: https://doi.org/10.20546/ijcmas.2020.910.345 